\title{
Covid-19 Pandemic and Its Effects on Dentistry: A Retrospective Study
}

\author{
Gulbahar Erdinc ${ }^{1}$,Neslihan Yilmaz Cirakoglu² \\ ${ }^{1}$ Karabuk University, Faculty of Dentistry, Department of Prosthodontics, Karabuk, Turkey. \\ ${ }^{2}$ Karabuk University, Faculty of Dentistry, Department of Endodontics, Karabuk, Turkey. \\ Correspondence Author: Neslihan Yilmaz Cirakoglu \\ E-mail: neslihanyilmazcirakoglu@karabuk.edu.tr
}

Received: $17.06 .2021 \quad$ Accepted: 18.08 .2021

\begin{abstract}
Objective: The purpose of this study was to compare patient admissions, treatment needs, and treatments in our hospital before and after the Covid-19 pandemic.

Methods: The patients who presented to Karabük Oral Dental Health Training and Research Hospital between March 2019 and March 2021 were retrospectively evaluated. The data obtained were used to compare the 1-year process after the Covid-19 pandemic and the 1-year process before the Covid-19 pandemic. In this 2-year period, the number of hospital registrations, distribution of patients by gender, age data, type, and the number of procedures performed were obtained from the software system used in the hospital.

Results: The average number of patients admitted to the hospital per month in 1 year before the pandemic is approximately 3.5 times in the next 1 year. When the number of patients applying was evaluated in terms of gender, it is seen that the number of male patients decreased more than women during the pandemic period. It has been observed that there is a dramatic decrease in the pandemic period in all treatments.

Conclusion: With the Covid-19 pandemic, there has been a serious decrease in the number of patients. However, with the ongoing treatment needs and normalization processes of the patients, necessary precautions were taken and the treatment of the patients continued.
\end{abstract}

Keywords: Covid-19, Dental procedures, Patient admission

\section{INTRODUCTION}

In 2019, a coronavirus that has not previously been detected in humans was identified in the Wuhan region of China. The World Health Organization (WHO) named this virus, which causes atypical pneumonia, as a novel coronavirus (2019-nCoV). It was later named SARS-CoV-2 because of its taxonomic similarity to the causative virus (SARS-CoV) of severe acute respiratory syndrome (SARS) $(1,2)$. WHO first announced this unique pneumonia as an epidemic threatening international public health on 30 January 2020, and then declared it a pandemic on 11 March 2020, as cases of infection occurred in many countries (3). The rapidly spreading coronavirus infection (Covid-19) has become a major health crisis worldwide. The first Covid-19 case in Turkey was officially announced by the Ministry of Health of the Republic of Turkey on 10 March 2020 (4).

Current data show that human-to-human transition of the new coronavirus type is easier and faster than for other coronavirus types (5). It has been reported that the route of transmission is directly from person to person or through infected saliva, respiratory tract, and droplets (6). Similar to SARS-CoV, SARS-CoV-2 enters the cell via the angiotensin converting enzyme-2 (ACE-2) cell receptor (7). ACE-2 cells are morphologically similar to salivary duct epithelium and are abundant along the airways. It has been found that ACE-2 cells are more abundant in the oral mucosa than in buccal and periodontal tissues, particularly on the dorsum of the tongue, and therefore dental practices are at high risk for Covid-19 (8).

Although it is not possible to identify people who are carriers of the virus without testing in the early period, it has also been reported that the infection can be transmitted through contact by persons who are asymptomatic carriers (9). In the pandemic period we are in, it is extremely important in terms of infection control that any patient coming into the clinic can transmit this virus without showing any signs and symptoms, and that the dentists and the entire team of assistants 
take appropriate precautions. Dental clinics are considered contamination areas that increase the spread of the disease in terms of cross-infection (10). Therefore, the measures and protocols required to control the risk of cross-infection during the Covid-19 epidemic have been established, and patient management has been implemented.

The Ministry of Health of Republic of Turkey published Covid-19 disease guide for health professionals and specified the measures to be taken. Then, with the recommendation of Coronavirus Scientific Advisory Board of General Directorate of Ministry of Health Services, a circular was issued that dental treatments should be postponed except for emergency and compulsory services (11). It was recommended that air-water sprayers and round hand tools be used at a minimal level, and ultrasonic hand tools should not be used in applications during this period. It was reported that procedures should be performed with hand tools and minimally invasive/atraumatic as much as possible (12). Some measures that can be taken are as follows: the clinic waiting area and examination room should be adequately ventilated, no companions should be brought into the treatment area except for patients who require assistance, aerosol-generating surgeries should be performed in isolated areas and scheduled as the last appointment of the day if possible. In addition to standard precautions (hand hygiene, use of gloves and surgical masks), personal protective equipment including FFP2/FFP3 (N95/ N99) filtered mask, face/eye protection and gown is required (13).

On 21 April 2020, the definition of Emergency and Compulsory Services in Dentistry Practices in the Covid-19 process was also made, and it was reported that dentists should continue to recruit patients in accordance with these guidelines (14). In the later stages of the pandemic, with the decline in the number of cases, the transition to the normalization period was made and the "Working Guide in Health Institutions in Normalization Period in Covid-19 Pandemic" was published by the Ministry of Health on 1 June 2020. Deferred elective treatments are now again performed according to the working principles of this guideline, especially in emergency and compulsory care (15).

The purpose of this study was to compare patient admissions, treatment needs, and treatments in our hospital before and after the Covid-19 pandemic. The study questions were as follows: 1) How have hospital admissions changed during the pandemic period compared to previous periods? 2) Is there a relationship between socio-demographic characteristics such as gender and age in the number of hospital admissions during the pandemic period? 3) How did the treatments provided in the hospital change during the pandemic period compared to the previous periods? The hypothesis of the study was that there is a significant decrease in the number of patient admissions in the early period of the epidemic compared to previous periods, and the majority of procedures performed on patients treated are in the context of emergency treatments.

\section{METHODS}

The study protocol was approved by the Karabük University Ethics Committee for Non-Interventional Clinical Research (Decision No: 2021/467). In this study, patients who presented to Karabük Oral Dental Health Training and Research Hospital between March 2019 and March 2021 were retrospectively evaluated. The data obtained were used to compare the 1-year process after the Covid-19 pandemic and the 1-year process before the Covid-19 pandemic. In this 2-year period, the number of hospital registrations, distribution of patients by gender, age data, type, and the number of procedures performed were obtained from the software system used in the hospital. For the 1-year periods before and after the Covid-19 pandemic, these data were collected separately for each month. Since the first Covid-19 case in our country was reported in March 2020, the distinction between the pre-and post-pandemic periods was made in March. Data were recorded monthly in order to evaluate the effects of the Covid-19 pandemic on the number of patients and the procedures performed. When evaluating patient admission, the classification by age was divided into 3 groups: 0-14, 1465 , and over 65 years old. The procedures performed are prosthodontic (crown recementation, removable denture applications, removable denture repair, and reline procedures, veneer crown removal), endodontic (root canal treatment, extirpation), pedodontic (fluoride application, fissure sealing, and space retainers), and surgical (extraction) were classified as procedures. All dental treatments were not included in the study. Only dental treatments were selected for the study, which are thought to be able to obtain more detailed data and can be considered as emergency or non-essential treatments that can be associated with the Covid-19 pandemic.

The number of patient admissions and the number of dental procedures performed were compared by calculating monthly averages for the 1-year periods before and after the Covid-19 pandemic. The distribution of patients according to the determined by age groups and gender was evaluated. The alterations in the numbers and types of dental procedures performed were determined.

\section{RESULTS}

In the retrospective screening, the average number of patients admitted to the hospital per month in the 12 months before March 2020 when the epidemic was first seen in Turkey and the 12 months after the epidemic, the change in the number of patients by age groups and by gender as 0-14, 15-64 and 65+ are shown (Table 1, Figure 1 and Figure 2). In addition, the numbers of patients who have had Covid-19 and patients admitted the dental hospital every month since March 2020 shown in Table 2. While there were a total of 183.275 patient applications in the one-year period before the Covid-19 pandemic, a total of 64.145 patient applications were made in the one-year period after the Covid-19 pandemic. The correlation of the number of patients with Covid-19 and the number of monthly patients admitted to our oral and dental health center is shown in Figure 3 . The 
average number of patients admitted to the hospital per month in 1 year before the pandemic is approximately 3.5 times in the next 1 year. When the number of patients applying is evaluated in terms of gender, it is seen that the number of male patients decreased more than women during the pandemic period. In addition, the average numbers of procedures performed (repair, cementation, prosthesis, veneer crown, crown removal, denture reline, fluoride application, fissure sealant, fixed retainer, extraction, extirpation, root canal treatment) per months are shown in Table 3 and Figure 4.

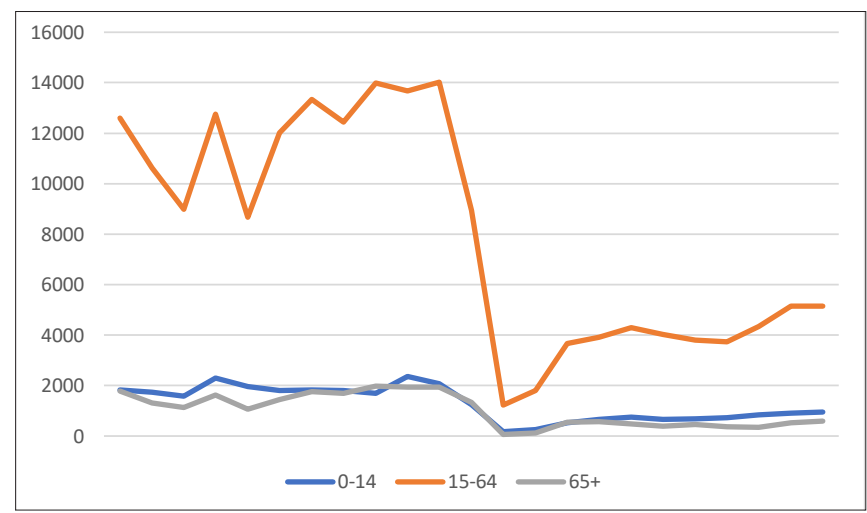

Figure 1. Distribution of the average numbers of patients admitted to the hospital per month in the 12 months before March 2020 and in the 12 months after the Covid-19 by age groups

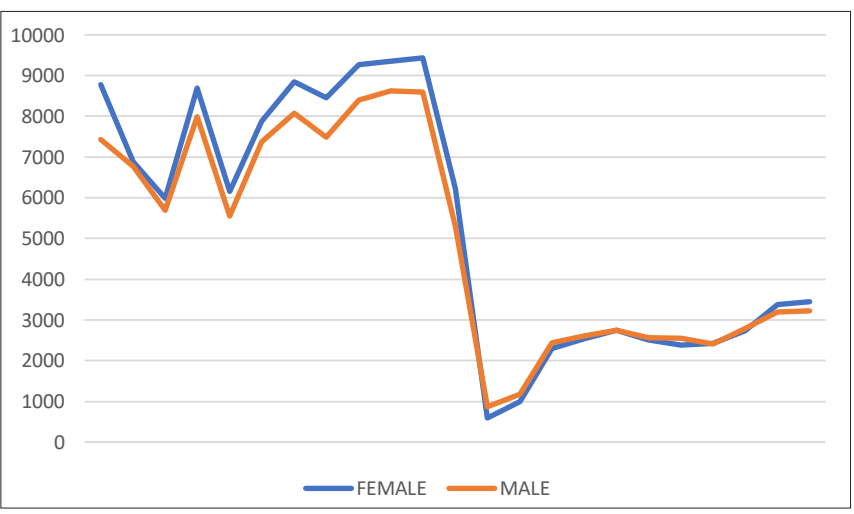

Figure 2. Distribution of the average numbers of patients admitted to the hospital per month in the 12 months before March 2020 and in the 12 months after the Covid-19 by gender

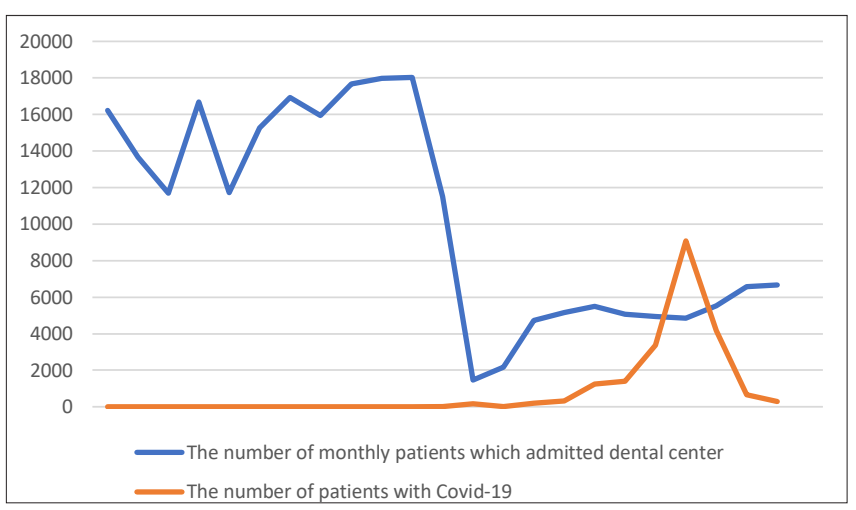

Figure 3. The correlation of the numbers of patients with Covid-19 and the average numbers of patients per month which admitted dental center

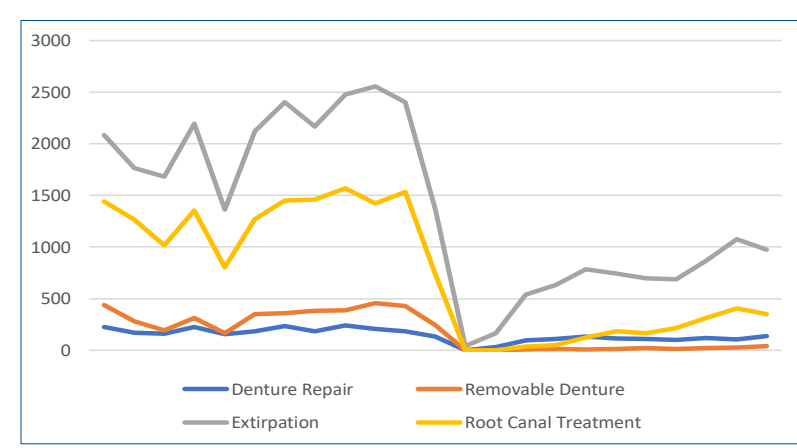

Figure 4. Average numbers of mainly dental procedures performed per month in the 12 months before March 2020 and in the 12 months after the Covid-19.

Table 1. Distribution of the average number of patients admitted to the hospital per month in the 12 months before March 2020 and in the 12 months after the Covid-19 by age groups and gender

\begin{tabular}{|c|c|c|}
\hline & Before Covid-19 & After Covid-19 \\
\hline $0-14$ age & 1853.33 & 627.33 \\
\hline $15-64$ age & 11838 & 3708.75 \\
\hline $65+$ age & 1581.58 & 389.41 \\
\hline Female patient & 7999.83 & 2273.16 \\
\hline Male patient & 14549.83 & 2333.41 \\
\hline
\end{tabular}

Table 2. Distribution of the number of patients with Covid-19 by months since the beginning of the pandemic in March 2020 in the city and numbers of patients who admitted to the dental hospital

\begin{tabular}{|c|c|c|}
\hline Date & $\begin{array}{c}\text { Numbers of Covid }(+) \\
\text { patients }\end{array}$ & $\begin{array}{c}\text { Numbers of admitted } \\
\text { patient }\end{array}$ \\
\hline March 2020 & 11 & 11520 \\
\hline April 2020 & 154 & 1462 \\
\hline May 2020 & 20 & 2168 \\
\hline June 2020 & 208 & 4735 \\
\hline July 2020 & 325 & 5148 \\
\hline August 2020 & 1250 & 5500 \\
\hline September 2020 & 1405 & 5075 \\
\hline October 2020 & 3364 & 4927 \\
\hline November 2020 & 9078 & 4837 \\
\hline December 2020 & 4163 & 5515 \\
\hline January 2021 & 657 & 6582 \\
\hline February 2021 & 278 & 6676 \\
\hline March 2021 & 1059 & 9366 \\
\hline April 2021 & 3628 & 7796 \\
\hline
\end{tabular}

Table 3. Average number of dental procedures performed in the hospital per month in the 12 months before March 2020 and in the 12 months after the Covid-19

\begin{tabular}{|c|c|c|}
\hline Dental procedures & Before Covid-19 & After Covid-19 \\
\hline Removable Denture Repair & 192.58 & 88.66 \\
\hline Cementation & 292.66 & 194.41 \\
\hline Removable Denture & 333.83 & 14.5 \\
\hline Veneer Crown & 604.16 & 0.83 \\
\hline Crown Remowal & 188.33 & 14.75 \\
\hline Denture Reline & 22.91 & 3.66 \\
\hline Fluoride Application & 72.41 & 11.83 \\
\hline Fissur Sealing & 114.41 & 8.5 \\
\hline Fixed Retainer & 21.16 & 9.6 \\
\hline Extraction & 2048 & 621.25 \\
\hline Extirpation & 145.25 & 60.33 \\
\hline Root Canal Treatment & 1276.75 & 164.08 \\
\hline
\end{tabular}




\section{DISCUSSION}

In our study, primary treatment needs were evaluated due to the changes in the number of patient applications to Karabük Oral and Dental Health Training and Research Hospital and the number of treatments during the 12 months before the Covid-19 pandemic and the following 12 months. As a result of the study, it was found that there was a dramatic decrease in the number of patients admitted to the hospital after the pandemic and in all treatment types. In the literature, it has been reported that SARS-CoV-2 virus was isolated in saliva samples obtained from Covid-19 cases (16). In addition, it has been reported that the SARS-CoV virus, which is a member of the same family but has similar features to this virus, can form the main source of the virus by infecting the salivary gland epithelial cells (17). Therefore, saliva contamination has an important place in the transmission of the disease (18). When asked to evaluate basic dentistry branches according to the risk they pose for saliva contamination in Covid-19, most of the participants in all three groups answered prosthetic dental treatment as the highest risk branch. Prosthetic dental treatment is a clinical branch that is very prone to the spread of intraoral fluids, as it includes operations such as tooth preparation and impression taking (19). In Benli's study, the most risky dental applications are; tooth preparation, tartar scaling, pulp extirpation and filling process (20). In line with this result, the highest rate of decline was observed in prosthetic applications (denture repair, crown cementation, removable denture, veneer crown, crown removal, denture reline) in our study.

Since our study was conducted on patients who applied to Karabük Oral and Dental Health Training and Research Hospital, when we examined the relationship between the distribution of the number of patients and the number of patients who had Covid-19 since March 2020, the first date of the pandemic, the increase in the number of cases showed a significant correlation in the number of patients admitted and the number of procedures performed. found to be absent.

Since all treatments applied by dentists are carried out very close to the mouth and nose, it increases the risk of transmission for both physicians and auxiliary staff, patients and relatives of all these individuals $(21,22)$. According to the current study by Meng et al. (23), it is not possible to definitively determine whether there is a Covid-19 infection in patients undergoing dental treatments, because there are individuals who are in the incubation period, have the disease without symptoms, or hide their disease. For this reason, Covid-19 has caused significant anxiety problems in dentists in terms of dental treatments. In addition, another reason for the decrease in the number of patients can be shown as the anxiety and reluctance of patients in need of treatment to go to hospitals and other health institutions due to the risk of contamination.

In a survey conducted by Ovalioğlu et al. (24), $11.2 \%$ of the patients reported that they would come to the endodontic clinic in non-emergency situations, and $88.7 \%$ of them reported that they would only apply to the endodontic clinic in an emergency. The women participants surveyed stated that they were more anxious and fearful than man participants who were more willing to go to the dentist appointment. The fact that the rate of wanting to apply even to a department such as endodontics, which requires the most urgent treatment and where the majority of patients apply with severe pain, can provide us with an idea for other dental procedures. In addition, when we look at the types of dental procedures performed, it is seen that there is a greater decrease in the procedures other than the applications considered as emergency dentistry applications after Covid-19, compared to the emergency ones. According to a study conducted by Aras et al. (25) to evaluate the knowledge level of the Turkish Community about emergency dentistry practices after the Covid-19 Epidemic. Although some of the participants are still not aware of the seriousness of Covid-19, it has been shown that the majority of them are aware of the contamination risk in dental clinics and have sufficient knowledge about emergency dental treatments. In addition, the dramatic decrease in the number of treatments and patients, especially in the first months after the declaration of the pandemic, may be due to the fact that physicians and other clinical staff do not have enough information about the Covid-19 outbreak. In a study by Dikilitaş et al. (26), it was stated that the level of knowledge of dentistry health workers on the prevention and control of Covid-19 in general is low and they should be trained on this subject and regularly renew this knowledge and experience in order to protect against new infections that may occur in the future.

Ağmaz et al. (27) evaluated the applications made to the pediatric dentistry clinic retrospectively as a period of 3 months and 5 years before the Covid-19 pandemic. It has been shown that there is a significant decrease in the applications made to the hospital and the procedures performed during the Covid-19 pandemic period. They stated that the treatment aims and methods in dentistry, which is an area with a very high risk of transmission, will be reviewed after Covid-19. The reason for the decrease in patient admissions due to the treatments given may be the curfews applied especially for children and the elderly. One study found that restrictions imposed to prevent the spread of Covid-19 caused a significant decline (81\%) in oral health care intake for older adults (28). In addition, in pediatric patients, parents may have made their own palliative treatments by looking at their old prescriptions, and therefore, applications and treatments may have decreased. In the study of Tunç et al. (29), in which they aimed to evaluate the knowledge, attitudes and practices of parents about self-medication for their children's dental problems during the Covid-19 epidemic, it was stated that the majority of parents ( $n=273 ; 70.2 \%)$ used self-medication for their children's dental problems. It was concluded that drug treatment with previously prescribed drugs was generally preferred by parents $(n=179 ; 62.2 \%)$ and analgesics (98\%) were the most self-administered drugs for their children's dental problems. 
Due to the unpredictability of the pandemic, the measures that can be taken and additional protective procedures before treatment are practically insufficient. For this reason, interventional procedures have been reduced and even stopped since the declaration of the pandemic. In our study, we preferred a public institution because it is easier to obtain patient records and covers a wider population. However, we think that this dramatic decrease in treatments and number of patients is similar in private clinics. It is inevitable that patient flows are not as high as they used to have economic effects. Among these effects, the decrease in working hours with the transition to flexible working hours can be counted as the dismissal of salaried dentists and other clinical staff $(30,31)$. These situations can lead to unpredictable longterm results such as unemployment. While the lockdowns and reductions in dental activities have a profound impact on the economy of this sector, all dental procedures during the Covid-19 outbreak should be continued with all precautions taken (32). An important consequence of this dramatic decrease in the number of treatments is that patients cannot have the necessary dental treatments, so there may be serious deterioration in oral and dental health, and advanced treatments require more costs.

The fact that patients prefer private clinics instead of public institutions may also be effective in the dramatic decrease in the number of patients in our hospital after the epidemic. Şahin et al. (33), in a study they conducted, aimed to evaluate the patients' thoughts about dental practices and preventive measures and to compare their thoughts on the risk of transmission according to the preferences of the institution. As a result of the study, it was determined that $69.30 \%$ of the participants preferred private clinics for dental treatments, $18.80 \%$ preferred dental faculties and $11.90 \%$ preferred oral and dental health centers and hospitals. It has been determined that there is a statistical relationship between the state of the patients thinking that they are adequately protected against the risk of Covid-19, the state of thinking that the Covid-19 epidemic is under control, and the anxiety caused by the crowd in the waiting area and institution preferences.

The limitations of this study are that the study is limited to only one public hospital and covers a limited time. Future studies can be planned to be evaluated over more clinics providing dental services and for longer time intervals.

\section{CONCLUSION}

With the increase in Covid-19 cases in the early stages of the pandemic, there has been a significant decrease in the number of patients admitted to dental hospitals and the procedures performed. However, first of all, since the treatment needs of the patients continued, necessary precautions were taken and emergency treatments were started. Then, with the normalization period, routine dental procedures of the patients began to be performed. Dentistry is a profession that has a high risk of cross infection due to its nature, but infection control training is very strict. For this reason, the dental treatment of the patients should be continued by taking the necessary precautions.

Conflict of Interest: There are no conflicts of interest in connection with this paper.

\section{REFERENCES}

[1] Lu H, Stratton CW, Tang YW. Outbreak of pneumonia of unknown etiology in Wuhan, China: The mystery and the miracle. J Med Virol 2020;92:401-402.

[2] WHO. Novel coronavirus-China. Jan 12, 2020. Date: 18.05.2020. Available: http://www.who. int/csr/don/12january - 2020-novel-coronavirus-china/en/.

[3] WHO Director-General's opening remarks at the media briefing on Covid-19 - 11 March 2020.[Internet]. World Health Organization, 2020. Date: 18.05.2020. Available: https://www. who.int/dg/speeches/detail/whodirector-general-s-openingremarks-at-themedia-bri.

[4] World Health Organization [Internet]. Global research on coronavirus disease (COVID-19). [cited 2020 April 10]. Available from: https://www.who.int/emergencies/diseases/ novel-coronavirus -2019 ? gclid=CjwKCAjwxqX4BRBhEiwA YtJX7WnnjOEOY-n6rPHW2iNUsmswueudihM.

[5] Liu Y, Gayle AA, Wilder-Smith A, Rocklöv J. The reproductive number of Covid-19 is higher compared to SARS coronavirus. J Travel Med 2020.

[6] Peng X, Xu X, Li Y, Cheng L, Zhou X, Ren B. Transmission routes of 2019-nCoV and controls in dental practice. Int J Oral Sci 2020;12:9.

[7] de Wit E, van Doremalen N, Falzarano D, Munster VJ. SARS and MERS: recent insights into emerging coronaviruses. Nat Rev Microbiol 2016;14:523-534.

[8] Xu H, Zhong L, Deng J, Peng J, Dan H, Zeng X, Li T, Chen Q. High expression of ACE2 receptor of 2019-nCoV on the epithelial cells of oral mucosa. Int J Oral Sci 2020;12:8.

[9] Rothe C, Schunk M, Sothmann P. Transmission of 2019-nCoV infection from an asymptomatic contact in Germany. N Engl J Med 2020;382:970-971.

[10] Soysal F, İşler SÇ, Akça G, Ünsal B, Özmeriç N. Covid-19 pandemi döneminde diş sağlığı hizmetlerinde yer alan yardımcı ekibin enfeksiyon kontrolündeki rolü. Gazi Sağlık Bilimleri Dergisi 2020;52-71. (Turkish)

[11] T.C. Sağlık Bakanlığı Halk Sağlığı Genel Müdürlüğü.Covid-19 (SARS-CoV-2 Enfeksiyonu) Bilim Kurulu Çalışması. Erişim Tarihi: 14.04.2020. Erişim Adresi: https://covid19bilgi.saglik.gov.tr/ depo/rehberler/COVID-19_Rehberi.pdf?type=file. (Turkish)

[12] Dentistry Workers and Employers. Occupational Safety and Health Administration, 2020. Date: 18.05.2020. Available: https://www.osha.govSLTC/covid-19 dentistry.html.

[13] Şenel FÇ. Covid-19 salgınının diş hekimliği uygulamalarına etkisi. ADO Klinik Bilimler Dergisi 2021;10:1-12. (Turkish)

[14] T.C. Sağlık Bakanlığı. COVID-19 Diş Hekimliği Uygulamalarındaki Acil ve Zorunlu Hizmetler. Sağlık Bakanlığı; 2020 Erişim: https:// covid19bilgi.saglik.gov.tr/depo/enfeksiyon-kontrol-onlemleri/ COVID19DisHekimligiUygulamalarindakiAcilVeZor. (Turkish)

[15] T.C. Sağlık Bakanlığı. Covid-19 Saglik Kurumlarinda Çalisma Rehberi ve Enfeksiyon KontrolÖnlemleri.https://covid19. saglik.gov.tr/ E k lenti / 39606 / 0 covid 19 saglikku $\mathrm{ru} \mathrm{m} \mathrm{la} \mathrm{rind} \mathrm{a} \mathrm{c} \mathrm{a} \mathrm{li} \mathrm{s} \mathrm{m}$ a rehberiveenf. 
[16] To KKW, Tsang OTY, Yip CCY, Chan KH, Wu TC, Chan JMC. Consistent detection of 2019 novel coronavirus in saliva. Clin Infect Dis 2020;71:841-843.

[17] Liu L, Wei Q, Alvarez X, Wang H, Du Y, Zhu H. Epithelial cells lining salivary gland ducts are early target cells of severe acute respiratory syndrome coronavirus infection in the upper respiratory tracts of rhesus macaques. J Virol. 2011;85:40254030.

[18] Alharbi A, Alharbi S, Alqaidi S. Guidelines for dental care provision during the Covid-19 pandemic. Saudi Dent J 2020;32:181-186.

[19] Atalay $Y$, Asutay F, Cakmak O. Dentistry and cross-infection control. J Dent 2014;116:44-46.

[20] Benli M. Attitudes and awareness levels of prosthodontists for Covid-19 transmission.

[21] Volgenant CMC, de Soet JJ. Cross-transmission in the dental office: does this make you ill? Current Oral Health Reports 2018;5:221-228.

[22] Peng X, X X X, Li Y, Cheng L, Zhou X, Ren B. Transmission routes of 2019-nCoV and controls in dental practice. Int J Oral Sci 2020;12:1-6.

[23] Meng L, Hua F, Bian Z. Coronavirus disease 2019 (COVID-19): emerging and future challenges for dental and oral medicine. J Dent Res 2020;99:481-487.

[24] Tysiąc-Miśta M, Dziedzic A. The attitudes and professional approaches of dental practitioners during the Covid-19 outbreak in poland: A cross-sectional survey. Int J Environ Res Public Health 2020;17:4703.

[25] Ovalıoğlu Z, Bozkurt DA, Akman M. Covid-19 pandemi sürecinde endodonti kliniğine gelen hasta anksiyete düzeyi. NEU Dent J 2020;2:98-102.

[26] Aras A, Akyol S, Yıldız S. Türk toplumunun Covid-19 salgını sonrası belirlenen acil diş hekimliği uygulamaları hakkındaki bilgi seviyelerinin değerlendirilmesi. J Harran Unıv Med Fac 2020;17:360-365. (Turkish)

[27] Dikilitaş A, Karaaslan F, Evirgen Ş. Evaluation of the knowledge and attitudes of dental health care workers regarding the new coronavirus disease-2019 outbreak. Meandros Med Dent J 2021; 22:62-69.

[28] Ağmaz O, Özer H, Abaklı İnci M. Çocuk diş hekimliği kliniğine yapılan başvuruların retrospektif değerlendirilmesi: 5 yıl karşısında Covid-19 pandemisiyle 3 ay. NEU Dent J 2020;2:913. (Turkish)

[29] Lundberg A, Hillebrecht AL, McKenna G, Srinivasan M. Covid-19: Impacts on oral healthcare delivery in dependent older adults. Gerodontology 2020;00:1-5.

[30] Sen Tunc E, Aksoy E, Arslan HN, Kaya Z. Evaluation of parents' knowledge, attitudes, and practices regarding selfmedication for their children's dental problems during the Covid-19 pandemic: a cross-sectional survey. BMC Oral Health 2021;21:1-7.

[31] Wolf TG, Zeyer O, Campus G. Covid-19 in switzerland and liechtenstein: A cross-sectional survey among dentists' awareness, protective measures and economic effects. Int J Environ Res Public Health 2020;17:9051.

[32] Patel N. Impact on dental economics and dental healthcare utilization in Covid-19: an exploratory study. J Adv Oral Res 2020;11:128-136.

[33] Tahir Abdalqadir M. Covid-19 outbreak: routes of transmission, precautions, and economic impact on dentistry-a review article. Kurdistan J Appl Res. 2020:23-30.

[34] Sahin, O. Cinel Sahin, S. Türkiye'de Covid-19 normalleşme sürecinde hastaların dental tedavilere bakış açısının ve kurum tercihlerinin incelenmesi. Ank Med J 20:869-881. (Turkish)

How to cite this article: Erdinc G, Cirakoglu Yilmaz N. Covid-19 Pandemic and Its Effects on Dentistry: A Retrospective Study. Clin Exp Health Sci 2021; 11: 819-824. DOI: 10.33808/clinexphealthsci.953713 